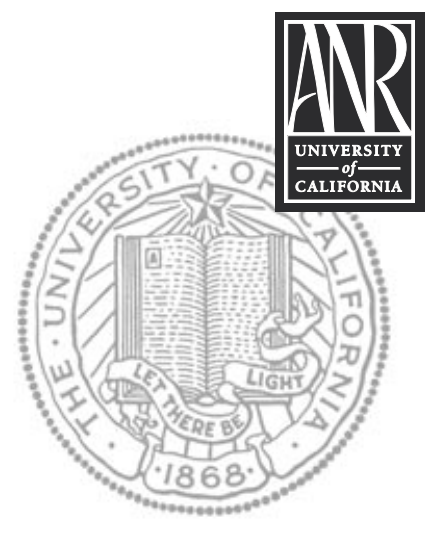

UNIVERSITY OF CALIFORNIA

Division of Agriculture and Natural Resources http://anrcatalog.ucdavis.edu

\title{
Mulches in California Vegetable Crop Production
}

JEFFREY MITCHELL, Vegetable Crops Specialist, Department of Vegetable Crops and Weed Science, University of California, Davis; CHARLES SUMMERS, Entomologist, Department of Entomology, University of California, Davis; MILT MCGIFFEN, University of California Cooperative Extension Vegetable Crops Specialist, Department of Botany and Plant Sciences, University of California, Riverside; JOSE AGUIAR, University of California Cooperative Extension Farm Advisor, Riverside County; SAM ASLAN, USDA Natural Resources Conservation Service, Indio, CA; JIM STAPLETON, IPM Plant Pathologist, Statewide IPM Program, University of California, Davis

Surface mulches are widely used in the production of strawberries and certain highvalue vegetable crops. Polyethylene mulch is used on virtually all tomato and strawberry production in Florida and is also widely used in the production of other crops such as peppers, eggplant, and melons throughout much of the southern United States. Researchers at the University of Florida estimate that more than 100,000 acres (40,500 ha) of vegetable crops in that state currently use plastic mulches annually, making Florida the national leader in this production system (Olson 1995). In California, the majority of strawberry and staked tomato production uses polyethylene mulch. Peppers, eggplant, and melons also use mulches in certain situations, especially when earliness is desired. Field management and research related to plastic mulches in these production regions is now quite developed. Potential benefits as well as drawbacks of polyethylene mulches for vegetable crop production are given in table 1 .

The use of intercrop cover crop residues as surface mulches is a more recent and far less widely used production practice. It has recently gained considerable interest in a number of commercial vegetable crop production regions in the United States. The use of organic mulches in smaller-scale gardening contexts has had a very long history. Potential advantages and disadvantages of this vegetable crop production technique are summarized in table 2.

Reflective plastic and some cover crop mulches share similar features relative to crop production: insect and disease management, weed management, fertilizer availability, and water conservation.

In order for production practices using either polyethylene or cover crop mulches to be successfully adopted in California, specific production goals must be carefully matched with specialized management know how and experience.

\section{PLASTIC MULCHES}

Plastic mulches have been commonly used for commercial vegetable crop production for more than 30
Table 1. Benefits and problems associated with the use of polyethylene mulches for vegetable crop production

\begin{tabular}{|c|c|}
\hline Benefits & Problems \\
\hline $\begin{array}{l}\text { •crop earliness } \\
\text { • increased yields } \\
\text { •improved crop quality } \\
\text { - reduced fertilizer leaching } \\
\text { - reduced soil water evaporation } \\
\text { - weed suppression } \\
\text { - management of insect pests } \\
\text { and diseases } \\
\text { - enhanced nitrogen availability }\end{array}$ & $\begin{array}{l}\text {-removal and disposal } \\
\text {-higher production costs } \\
\text { •specialized management and } \\
\text { equipment required } \\
\text {-increased susceptibility to frost }\end{array}$ \\
\hline
\end{tabular}


Table 2. Benefits and problems associated with the use of cover crop mulches for vegetable crop production

\begin{tabular}{|c|c|}
\hline Benefits & Problems \\
\hline $\begin{array}{l}\text { •weed suppression } \\
\text { •enhanced nitrogen availability } \\
\text { •reduced soil erosion } \\
\text { • increased soil organic matter } \\
\text { •reduced intercrop tillage } \\
\text { • increased soil quality } \\
\text { - offset payment incentives possible } \\
\text { through U.S. Farm Bill conservation } \\
\text { programs } \\
\text { • insect and disease suppression }\end{array}$ & $\begin{array}{l}\text { •cooler temperatures above and } \\
\text { below mulch } \\
\text { • slower-maturing crops } \\
\text { •cover crop mulch regrowth } \\
\text { - specialized management required } \\
\text {-in-season weed management } \\
\text { options are limited } \\
\text { - costs } \\
\text {-alleopathy }\end{array}$ \\
\hline
\end{tabular}

years. Excellent sources of information on specific characteristics and applications of plastic mulches are available on the World Wide Web, and several of these are provided in the references to this publication. Most plastic mulch materials are made of either high- or low-density polyethylene, ranging from 0.30 to 0.79 inches ( 7.7 to $20.2 \mathrm{~mm}$ ) in thickness, are 5 to 6 feet ( 1.5 to $1.8 \mathrm{~m}$ ) wide, and are available on rolls 555 to 1,338 yards (506 to $1,223 \mathrm{~m}$ ) long, depending on the thickness of the mulch (Lamont 2001).

The color of mulch is an important determinant of the microclimate around a crop plant. Black, white, and clear plastic mulches are most commonly used in commercial production, with black being the dominant color used for vegetables. Black plastic mulch is typically used for spring-seeded crops because it increases soil temperatures about $5^{\circ} \mathrm{F}\left(2.8^{\circ} \mathrm{C}\right)$ at a depth of 2 inches $(5 \mathrm{~cm})$ and $3^{\circ} \mathrm{F}\left(1.7^{\circ} \mathrm{C}\right)$ at 4 inches $(10 \mathrm{~cm})$, compared to those of bare soil (Lamont 2001). Recently, a mulch has been introduced that consists of a strip of black plastic $30 \mathrm{~cm}$ (11.8 in) wide down the center that is flanked on either side by metalized reflective plastic. This plastic combines the advantages of black plastic over the seed row, to help heat the soil, with the reflective characteristics of metalized plastic for insect and disease management. Black mulches have also recently been shown to reduce weed growth. White or coextruded white-on-black mulches can slightly lower surface soil temperatures by about $1^{\circ} \mathrm{C}$ at $2 \mathrm{~cm}$ depth or $0.4^{\circ} \mathrm{C}$ at 10 $\mathrm{cm}\left(1.8^{\circ} \mathrm{F}\right.$ at 0.79 in or $0.72^{\circ} \mathrm{F}$ at 4 in) relative to bare soil because they reflect most incoming radiation (Lamont 2001). These mulches are used when lower soil temperatures may be desirable for planting vegetables in particular summer production windows. Clear mulches effectively retain much of the heat normally lost to the atmosphere by bare soil, increasing daytime soil temperatures from $4^{\circ}$ to $8^{\circ} \mathrm{C}$ ( $7^{\circ}$ to $13^{\circ} \mathrm{F}$ ) at a depth of $5 \mathrm{~cm}(2 \mathrm{in})$, and $3^{\circ}$ to $5^{\circ} \mathrm{C}\left(5^{\circ}\right.$ to $\left.8^{\circ} \mathrm{F}\right)$ at $10 \mathrm{~cm}$ (4 in) relative to bare soil (Lamont 2001). These clear plastics are the choice for soil solarization. Clear plastics, however, do not control weeds and require other weed management practices such as fumigation and herbicide application. Plastic mulches also influence nutrient levels and uptake. Wien and Minotti (1987) found plastic mulching increased shoot concentrations of nitrogen $(\mathrm{N})$, nitrate $\left(\mathrm{NO}_{3}-\mathrm{N}\right)$, phosphorus $(\mathrm{P})$, potassium $(\mathrm{K})$, calcium $(\mathrm{Ca})$, magnesium $(\mathrm{Mg})$, copper $(\mathrm{Cu})$ and boron $(\mathrm{B})$ in transplanted tomatoes. Bhella (1988), also working with tomatoes, found higher levels of ammonium $\left(\mathrm{NH}_{4}-\mathrm{N}\right)$, nitrate $\left(\mathrm{NO}_{3}-\mathrm{N}\right)$, and magnesium in plastic mulched soils. Hassan et al. (1995) found higher levels of nitrogen, phosphorus, potassium, and calcium in leaf tissue of chilies grown over plastic reflective mulch compared to those grown over bare soil.

A wide variety of other colored plastic mulches, including red, yellow, silver, blue, gray, and orange, have been used in various efforts to achieve specific production goals. Each of these colors has distinct spectral reflectivity characteristics and thus modifies the radiation balance in and below a crop canopy. These colored mulches affect not only the microclimate around a crop but have also been shown to influence insect behavior. Yellow, for example, is generally highly attractive to insects and has been shown to increase green peach aphid (Myzus persicae) and striped (Diabrotica undecimpunctata) and spotted (Acalymma trivitatum) cucumber beetle populations compared to plants grown over bare soil (Lamont 2001). White at times repels aphids and at other times attracts them, depending on the physiological state of the insect (Kring 1972). Orange has been shown to repel various aphids (Jones and Chapman 
1968) and whiteflies (Csizinszky et al. 1995), while pink and green attract aphids (Jones and Chapman 1968). Red has been shown to attract both aphids and whiteflies (Jones and Chapman 1968). Blue has been shown to be repellent in some studies (Basky 1984; Jones and Chapman 1968) and attractive in others (Corsoro et al. 1980; Csizinszky et al. 1995). Highly reflective or shiny aluminum plastic mulches have been shown to repel certain aphids and thereby reduce or delay the onset of aphid-vectored mosaic viruses in zucchini squash (Lamont 2001; Summers et al. 1995; Summers and Stapleton 2002a) and melons (Summers et al. 2004b; Stapleton and Summers 2002) and tomato spotted wilt virus (Tospovirus) in tomatoes (Olson 1995). These are the mulches of choice when insect and disease management are the principal objective. On balance, other than UV-metalized reflective mulches, repeated and consistent benefits in managing insects with most colored mulches have not been documented.

Colored plastic mulches have also been used in many parts of the United States to enhance yields. These mulches, however, have produced mixed results (Greer and Dole 2003). Mahmoudpour and Stapleton (1997) noted that "the influence of mulch colour on growth and productivity has been postulated to be highly specific, and may vary with plant taxa, climate, and seasonal conditions." As is the case with insect management, aluminum mulches have provided the most positive and consistent findings on crop production (Greer and Dole 2003).

\section{COVER CROP MULCHES}

Using cover crops as mulches is a relatively recent management strategy that is currently being refined and evaluated in a wide range of vegetable production systems. The winter annual legume hairy vetch (Vicia villosa), for example, has been used successfully as both a cover crop and as a mulch in fresh market tomato production systems in the southeastern United States. As a cover crop, the vetch fixes nitrogen, recycles nutrients, reduces soil erosion, and adds organic matter to the soil. When mowed and converted to a mulch, the vetch reduces weed emergence, lowers soil temperatures during the hot summer months, reduces water loss from the soil, and acts as a slow-release fertilizer (Abdul-Baki and Teasdale 1994). This system, developed by USDA ARS researchers, eliminates tillage, reduces the need for applying synthetic fertilizers and herbicides, and reportedly adapts to both large- and small-scale tomato production in a low-input, no-tillage system. Recent work in Florida by Chellemi et al. (1999) has shown that although a cover crop (bahiagrass, Paspalum notatum) surface residue mulch production system had lower yields than the standard black polyethylene plastic, the overall profitability of the alternative system was actually higher.

Work in California's Central Valley has shown that cover cropping increases water infiltration and reduced winter runoff (Joyce et al. 2002) and increases soil carbon (Poudel et al. 2001; Mitchell et al. 2003). Additionally, cover crops, when cut and dried, have been shown to delay and reduce the incidence of aphids and whiteflies as well as the incidence of aphidborne viruses. Burton and Krenzer (1985) observed a reduction in greenbug (Schizaphis graminum) populations where surface residues of a previous wheat crop existed. Summers et al. (2004a, b) found wheat straw mulch significantly delayed and reduced the incidence of alate aphids (Aphis gossypii) and several aphidborne cucurbit viruses in zucchini squash. The incidence of silverleaf whitefly (Bemisia argentifolii) and squash silverleaf (a physiological condition caused by the feeding of the silverleaf whitefly) was also significantly reduced. Similar results were obtained with cantaloupe grown over wheat straw residue. A number of other examples of the successful use of cover crop mulches have been reported in Georgia, Virginia, North Carolina, and Pennsylvania, but their potential in California's vegetable crop production is only now beginning to be investigated, evaluated, and refined. Combining the potential benefits of surface residue cropping alternatives with those of 
conservation tillage is becoming increasingly attractive to row crop producers in many of California's agricultural regions as shown by the following case studies.

\section{Cover Crop Mulch Tomato Production}

Beginning in 1995, a series of studies and demonstrations were initiated in the Central Valley to evaluate and develop conservation tillage (CT) and cover crop mulch production systems for tomato crop rotations. While the immediate goal of these efforts was to reduce production costs, a longer-term objective was to develop information on the potential of reduced tillage to improve soil quality, store carbon in the soil, and conserve resources. Initial studies, conducted at the University of California (UC) West Side Research and Extension Center in Five Points, at the UC Davis campus, and in commercial production fields in Tracy, Vernalis, and Le Grand, evaluated the use of winter cover crops as surface mulches, the feasibility of no-till and strip-till transplanting, and options for in-season weed management. No-till transplanting requires the use of coulters or some form of residue manager to cut surface residues ahead of the transplanter shoe. Strip-till is a form of CT in which a set of coulter or shank implements tills a narrow band of soil 15 to $20 \mathrm{~cm}$ wide $(5.9$ to $7.9 \mathrm{in}$ ) to a depth of about 8 to $36 \mathrm{~cm}$ (3.1 to $14.2 \mathrm{in}$ ) only in the line into which transplants (or seeds) will be placed. Results from these preliminary evaluations have indicated that planting and harvesting both processing and fresh market tomatoes is possible and that yields comparable to those attained using standard winter fallow techniques may be achieved with certain reduced-till approaches that do not result in excessive cover crop regrowth or weed competition with the tomato crop. On-farm strip trial data for demonstrations conducted in 1999 in Tracy and in 2000 in Vernalis are given in table 3 .

This early work, and other experiments summarized by Herrero et al. 2001b, also revealed that in-season weed control by a surface cover crop mulch alone is not adequate. The authors of this publication have subsequently investigated and refined the use of a high-residue cultivator that is able to effectively slice through residues while cultivating weeds.

Cover crop mulch species selection and mulch management must be optimized if organic mulch tomato production is to expand in California. Care must be taken to avoid the use of certain cover crops such as sorghum-Sudan hybrid as mulches

Table 3. Processing tomato yields in California from onfarm demonstrations Tracy and Vernalis

Processing tomato

Tillage or cover crop system yield tons/acre (T/ha)

Tracy, 1999

Strip-till vetch cover crop

No-till vetch cover crop

$46.6(20.8)$

36.8 (16.4)

No-till winter weeds

$47.3(21.1)$

Strip-till winter weeds

$45.5(20.3)$

Fallow standard tillage

$47.3(21.1)$

Vernalis, 2000

No-till bell bean cover crop

$40.5(18.1)$

No-till vetch and bell bean cover crop

$39.3(17.5)$

No-till berseem clover cover crop

$30.8(13.7)$

No-till pea cover crop

$28.2(12.6)$

Fallow standard tillage because they are highly allelopathic to tomatoes and several other vegetable crops (Summers et al. in preparation). More efficient and low-risk production protocols for managing cover crop mulches in vegetable crop rotations must also be developed.

\section{UV-REFLECTIVE PLASTIC MULCH}

Aphid-transmitted virus diseases cause significant economic losses to California's multimillion-dollar vegetable crop industries annually. Over the past few years, production of fall melons (cantaloupe, honeydew, and mixed melons), squash (zucchini and crookneck and hard winter squash), peppers (bell and chili), and tomatoes (fresh market and processing) has been extremely difficult in certain regions of the San Joaquin Valley due to extensive virus epidemics and severe infestations of silverleaf whitefly (Bemisia argentifolii). Spring crops, while affected to a lesser extent, have also suffered significant losses by aphid-transmitted viruses and whitefly infestations. 
Several plant viruses are responsible for these epidemics, and most are capable of infecting all of the crops mentioned above. Among the most important viruses are cucumber mosaic virus (CMV), zucchini yellows mosaic virus (ZYMV), potato virus Y (PVY), and watermelon mosaic virus (WMV). These viruses are transmitted by aphids in a styletborne, nonpersistent manner. They are acquired and transmitted in as few as 15 seconds, and are transmitted by a large number of aphid species, all of which are abundant throughout California. Due to the rapidity with which the viruses can be acquired and transmitted, insecticides are of little value in preventing virus spread and under some circumstances may actually increase the rate of virus transmission and spread. This has not, however, dissuaded a large number of growers and PCAs from attempting to control the spread of these viruses by using insecticides.

UV-reflective mulches consist of a polyethylene base to which a thin coat of aluminum ions has been adhered. The mulches are collectively referred to as metalized mulches. These mulches reflect UV wavelength (Summers et al. 2004b), which confuses and repels incoming alate aphids, adult whiteflies, and leafhoppers (Circalifer truellus), reducing their incidence of alighting on plants (Kring 1972; Summers and Stapleton 2002a, b).

UV-reflective plastic mulches have been used successfully to reduce the incidence of aphidborne virus diseases in squash and other crops (Brown et al. 1993; Summers et al. 1995; Summers and Stapleton 2002b; Stapleton and Summers 2002). Brown et al. (1993) found silver plastic mulch superior to white, yellow, or black with yellow edges in repelling aphids in yellow crookneck summer squash. Plants grown on silver mulch produced significantly higher yields of marketable fruit than did those grown on bare soil. Mulches applied to the planting beds before seeding were effective in repelling alate aphids and delaying the onset of several virus diseases as well as the onset of silverleaf whitefly colonization and the appearance of squash silverleaf in spring and fall-planted zucchini squash in California's San Joaquin Valley (Summers et al. 1995; Summers and Stapleton 2002b). Disease symptoms in plants growing over these mulches appeared 10 to 14 days later than in plants growing on unmulched beds. In spring-seeded squash, approximately 30 percent of the plants on unmulched beds were infected with one or more viruses by the first harvest, while only 10 to 15 percent of those grown over the metalized mulches showed virus symptoms. In fall-planted trials, 100 percent of the plants grown on unmulched beds, with and without insecticide applications, were virus-infected by the first harvest.

Metalized mulches were generally more effective in repelling aphids and delaying virus onset than were white-pigmented mulches (Summers et al. 1995). Although plants grown over the metalized mulched plots eventually became infected, they continued to produce a significantly higher percentage of marketable fruit throughout the season than did the unmulched controls. In addition, squash, cantaloupes, cucumbers, and corn grown over reflective mulch produced marketable fruit 7 to 10 days earlier that plants growing over bare soil. Stapleton and Summers (2002) also showed than cantaloupe grown over reflective mulches yielded over 500 cartons of marketable fruit per acre compared to less than 50 cartons per acre from plants grown on bare soil. A delay of 4 to 6 weeks in infection by CMV in plants growing over reflective mulch allowed them time to mature and set a good crop of melon fruit before becoming infected. Even though the plants eventually became infected, the delay in infection permitted the harvest of a highly profitable crop. Summers and Stapleton (unpublished data) have shown that tomatoes grown over reflective mulches averaged approximately 7 percent virus-infected plants, while plants grown over bare soil averaged in excess of 50 percent infection with the same viruses. This approach is currently the only viable means of managing virus disease in these production systems.

Growers are cautioned to use only metalized reflective mulches when insect and 
disease management is the primary objective. Other colors lack the high degree of UV reflectance necessary to repel incoming insects. Also, the mulch must be applied prior to seedling emergence. Plants may be inoculated with aphidborne viruses in the cotyledon stage, and any delay in applying the mulch could lead to an extensive infection. Some crops are more susceptible to injury when planted over metalized mulches. Tomatoes may suffer some leaf burn and early stunting (at 5 to 7 days) but rapidly outgrow these problems and soon surpass plants grown over bare soil. Eggplant tends to be more sensitive and may suffer prolonged injury. We have observed no problems with any cucurbits grown over metalized mulches. Plants, particularly cucurbits, grown over metalized mulches may be more susceptible to frost injury in the late fall. More widespread adoption of the use of UV-reflective plastic mulches in California has not occurred largely because of added costs (generally estimated to be at least $\$ 250$ per acre, or about $\$ 620$ per ha) associated with their use and disposal and a general lack of familiarity with production techniques required for their successful use.

\section{COWPEA COVER CROP MULCHES IN DESERT VALLEYS}

Southern California's Coachella and Imperial Valleys are major production regions for a wide variety of winter vegetables. Fields in these valleys are typically fallowed during the summer due to high temperatures that preclude the production of most vegetables. Recently, researchers at the University of California, Riverside, in conjunction with Riverside County Cooperative Extension, the Indio USDA Natural Resources Conservation Service, and the USDA Agricultural Research Service in Beltsville, Maryland, developed a cover crop mulch production system for this region using cowpea (Vigna unguiculata L.), a warm-season legume. This system relies on the use of large, bush-type cultivars. The cowpea is seeded into preshaped soil beds in June and August. When the cover crop is chopped and converted into a mulch, the aboveground biomass can be as much as 2,542 pounds per acre $(2,847 \mathrm{~kg} / \mathrm{ha})$, providing a surface matte that has been shown to control weeds, reduce parasitic nematodes, and provide for vegetable yields comparable to the current bare soil production system. This cover crop mulch production technique has also resulted in increased soil carbon, which is an important management goal of producers in the region.

\section{FUTURE PROSPECTS}

To remain competitive in future markets, California vegetable crop producers must constantly develop and refine cost-effective and environmentally sound production systems. As producers continue to tighten efficiencies in their vegetable crop production systems, the use of plastic and cover crop mulches may become a more common means to achieve specific management goals. Innovation and persistence will be required to assure successful adoption.

\section{REFERENCES}

Abdul-Baki, A. A., and J. R. Teasdale. 1994. Sustainable production of fresh-market tomatoes and other summer vegetables with organic mulches. USDA ARS Farmers' Bulletin No. 2279.

Basky, Z. 1984. Effect of reflective mulches on virus incidence in seed cucumbers. Protection Ecol. 6:57-61.

Bhella, H. S. 1988. Tomato response to trickle irrigation and black polyethylene mulch. J. Amer. Soc. Hort. Sci. 113:543-546.

Brown, J. E., J. M. Dangler, F. M. Woods, M. C. Henshaw, W. A. Friggy, and M. W. West. 1993. Delay in mosaic virus onset and aphid vector reduction in summer squash grown on reflective mulches. HortSci. 28:895-896. 
Burton, R. L., and E. G. Krenzer Jr. 1985. Reduction of greenbug (Homoptera: Aphididae) populations by surface residues in wheat tillage studies. J. Econ. Entomol. 78:390-394.

Chellemi, D. O., F. M. Rhoads, S. M. Olson, J. R. Rich, D. Murray, G. Murray, and D. M. Sylvia. 1999. An alternative, low-input production system for fresh market tomatoes. Am. J. Altern. Agric. 14(2): 59-68.

Corsoro, S., D. L. Coffey, and P. Lambdin. 1980. Suppression of the turnip aphid, Lipathis erysimi (Kltb.), on cabbage by reflective mulches and acephate. Tenn. Agric. Expt. Stat. 116:36-37.

Csizinszky, A. A., D. J. Schuster, and J. B. Kring. 1995. Color mulches influence yield and insect pest populations in tomatoes. J. Amer. Soc. Hort. Sci. 120:778-784.

Dickson, R. C., and E. F. Laird. 1966. Aluminum foil to protect melons from watermelon mosaic virus. Plant Dis. Rep. 50:305.

Granberry, D. M., W. T. Kelley, W. O. Chance, W. McLaurin, K. A. Harrison, and D. Sanders. 1994. Plasticulture for commercial vegetable production. Athens: University of Georgia College of Agricultural and Environmental Sciences Cooperative Extension Service Bulletin 1108. http://www.ces.uga.edu/pubcd/bl108-w.html

Greer, L., and J. M. Dole. 2003. Aluminum foil, aluminum-painted, plastic, and degradable mulches increase yields and decrease insect-vectored viral diseases of vegetables. Hort Tech. 13:176-184.

Harpaz, I. 1982. Nonpesticidal acontrol of vector-borne viruses. In K. F. Harris and K. Maramorosch, ed., Pathogens, vectors, and plant diseases: Approaches to control. New York: Academic Press.

Hassan, S. A., A. R. Zainal, and M. F. Ramlan. 1995. Growth and yield of chili (Capsicum annuum L.) in response to mulching and potassium fertilization. Pertanika J. Trop. Agric. Sci. 1995:113-117.

Herrero, E. V., J. P. Mitchell, W. T. Lanini, S. R. Temple, E. M. Miyao, R. D. Morse, and E. Campiglia. 2001a. Soil properties change in no-till tomato production. Calif. Agric. 55(1): 30-34.

- 2001b. Use of cover crop mulches in a furrow irrigated processing tomato production system. HortTech. 11(1): 43-48.

Hochmuth, G. J., R. C. Hochmuth, and S. M. Olson. 2001. Polyethylene mulching for early vegetable production in North Florida. Gainesville: University of Florida Horticultural Sciences Department, Florida Cooperative Extension Service, Institute of Food and Agricultural Sciences Circular 805. http://edis.ifas.ufl.edu/BODY_CV213

Jones, F. R., and R. K. Chapman. 1968. Aluminum foil and other reflective surfaces to manipulate the movement of aphid vectors of plant viruses. Proc. North Central Branch Entomol. Soc. Amer. 23:146-148.

Joyce, B. A., W. W. Wallender, J.P. Mitchell, L. M. Huyck, S. R. Temple, P. N. Brostrom, and T. C. Hsiao. 2002. Infiltration and soil water storage under winter cover cropping in California's Sacramento Valley. Transactions of the ASAE. 45(2): 315-326.

Kring, J. B. 1972. Flight behavior of aphids. Annu. Rev. Entomol. 17:461-492.

Lamont, W. J. 2001. Vegetable production using plasticulture. Food and Fertilizer Technology Center. http://www.agnet.org/library/article/eb476.html

Mahmoudpour, M. A., and J. J. Stapleton. 1997. Influence of sprayable mulch 
color on yield of eggplant (Solanum melongena L., cv. Millionaire). Scient. Hort.70:331-338.

Mitchell, J. P., K. Klonsky, R. DeMoura, W. R. Horwath, R. J. Southard, D. S. Munk, K. J. Hembree, J. B. Baker, J. J. Veenstra, A. Iserte, E. Scott, and J. Solorio. 2003. Reduced tillage cotton and tomato rotation study in Five Points, CA: An evaluation after four years. In Proceedings, Conservation Tillage 2003: The California Experience. October 7 - 9, 2003. Tulare, Five Points, and Davis, CA.

Olson, S. M. 1995. Mulching. Gainesville: University of Florida Horticultural Sciences Department, Florida Cooperative Extension Service, Institute of Food and Agricultural Sciences, Document HS715. http://edis.ifas.ufl.edu/BODY_CV105

Poudel, D. D., H. Ferris, K. Klonsky, W. R. Horwath, K. M. Scow, A. H. C. van Bruggen, W. T. Lanini, J. P. Mitchell, and S. R. Temple. 2001. The Sustainable Agriculture Farming Systems Project in California's Sacramento Valley. Outlook on Agric.30(2): 109-116.

Summers, C. G., and J. J. Stapleton. 2002a. Management of corn leafhopper (Homoptera: Cicadellidae) and corn stunt disease in sweet corn using reflective mulch. J. Econ. Entomol. 95:325-330.

- 2002b. Use of UV reflective mulch to delay the colonization and reduce the severity of Bemisia argentifolii (Homoptera: Aleyrodidae) infestations in cucurbits. Crop Protection 21:921-928.

Summers, C. G., J. P. Mitchell, and J. J. Stapleton. 2004a. Management of aphidborne viruses and Bemisia argentifolii (Homoptera: Aleyrodidae) in zucchini squash using UV reflective plastic and wheat straw mulch. Environ. Entomol. In press.

- 2004b. Non-chemical insect and disease management in cucurbit production systems. Acta Hort. In press.

Summers, C. G., J. J. Stapleton, A. S. Newton, R. Duncan, R. Hart, and D. Hart. 1995. Comparison of sprayable and film mulches in delaying the onset of aphid-transmitted virus diseases in zucchini squash. Plant Dis. 79:1126-1131.

Summers, C. G., J. P. Mitchell, T. S. Prather, and J. J. Stapleton. In preparation. Allelopathic effects of sorghum-Sudangrass hybrid (Sudex) crop on subsequently transplanted tomatoes, broccoli, and lettuce.

Stapleton, J. J., and C. G. Summers. 2002. Reflective mulches for management of aphids and aphid-borne virus diseases in late-season cantaloupe (Cucumis melo L. var. cantalupensis). Crop Protec. 21:891-898.

Wien, H. C., and P. L. Minotti. 1987. Growth, yield, and nutrient uptake of transplanted fresh-market tomatoes as affected by plastic mulch and initial nitrogen rate. J. Amer. Soc. Hort. Sci. 112:759-763. 


\section{FOR FURTHER INFORMATION}

You'll find more information on mulching in the following ANR Communication Services publications:

Plasticulture in California Vegetable Production, Publication 8016, 2000

(available for free downloading at the ANR CS Web site at

http://anrcatalog.ucdavis.edu/pdf/8016.pdf)

Soil Solarization: A Nonpesticidal Method for Controlling Diseases, Nematodes, and

Weeds, Publication 21377, 1997

To order or obtain these publications, visit the ANR Communication Services online catalog at http://anrcatalog.ucdavis.edu. You can also place orders by mail, phone, or FAX, or request a printed catalog of our products from:

University of California

Agriculture and Natural Resources

Communication Services

6701 San Pablo Avenue, 2nd Floor

Oakland, California 94608-1239

Telephone: (800) 994-8849 or (510) 642-2431; FAX: (510) 643-5470

E-mail inquiries: danrcs@ucdavis.edu

An electronic version of this publication is available on the ANR Communication Services Web site at http://anrcatalog.ucdavis.edu.

\section{Publication 8129}

(C) 2004 by the Regents of the University of California, Division of Agriculture and Natural Resources. All rights reserved.

The University of California prohibits discrimination against or harassment of any person employed by or seeking employment with the University on the basis of race, color, national origin, religion, sex, physical or mental disability, medical condition (cancer-related or genetic characteristics), ancestry, marital status, age, sexual orientation, citizenship, or status as a covered veteran (special disabled veteran, Vietnam-era veteran or any other veteran who served on active duty during a war or in a campaign or expedition for which a campaign badge has been authorized). University Policy is intended to be consistent with the provisions of applicable State and Federal laws.

Inquiries regarding the University's nondiscrimination policies may be directed to the Affirmative Action/Staff Personnel Services Director, University of California, Agriculture and Natural Resources, 300 Lakeside Drive, 6th Floor, Oakland, CA 94612-3550 (510) 987-0096.

For a free catalog of other publications, call (800) 994-8849. For help downloading this publication, call (530) 754-5112.

pr-5/04-SB/CR

ISBN 978-1-60107-308-2

This publication has been anonymously peer reviewed for technical accuracy by University of California scientists and other qualified professionals. This review process was managed by the ANR Associate Editor for Vegetable Crops. 